\title{
An empirical analysis of corporate governance and firm value: Evidence from KSE-100 Index
}

\author{
Asad Khan*, Sarfaraz Tanveer and Umbreen Malik
}

Department of Management Sciences, University of Haripur, Pakistan

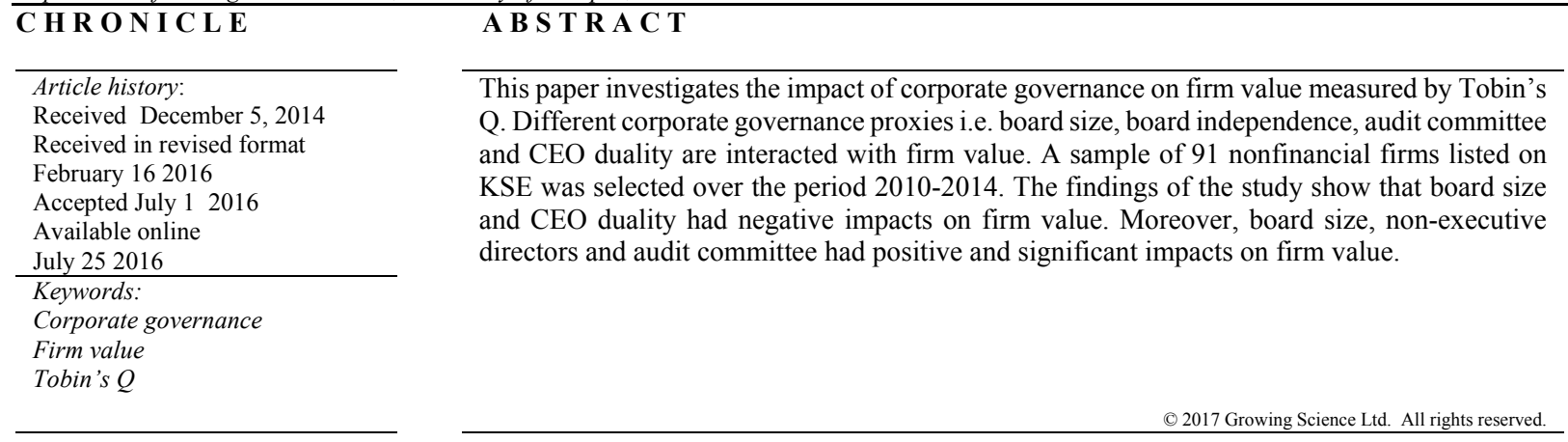

\section{Introduction}

The study of corporate governance in the field of management has traditionally highlighted and addressed the complexities of organizational decision such as Board composition, powers of executives and senior managers (Smith, 2014). Various studies over the years, on subject of corporate governance have shaped a unique combination of stakeholder's working relationship, risk management, employee's compensation and other challenges important to organization (Renders \& Gaeremynck, 2012; Huyghebaert \& Wang, 2012; Pindado, Requejo, \& de la Torre, 2012). Moreover, the constantly evolving organizational dynamics and business environment also give birth to new questions, issues and conflicting managerial roles and their new contexts to social and environmental complexities (King \& Wen, 2011). Challenges like that, always present an opportunity for mangers and policy maker to constantly fine tune the delicate strings of corporate governance in the best interest of their stakeholders.

The concept of corporate governance is deeply rooted into financial perspective. As highlighted by Shleifer and Vishny (1997) by raising key question at the heart of corporate governance as "the ways in which suppliers of finance to corporations assure themselves of getting a return on their investment. How do the suppliers of finance get managers to return some of the profits to them? How do they make

* Corresponding author.

E-mail address: asadkhan@uoh.edu.pk (A. Khan) 
sure that managers do not steal the capital they supply or invest it in bad projects? How do suppliers of finance control managers?" This point of view is built on the concept of Agency theory, which advocates the segregation of managerial control and ownership in organization (Jensen \& Meckling, 1976). According to recent studies and industry's critique, the concept of corporate governance has mushroomed out from the shell of narrow financial prudence, and gradually added more dynamic roles such as a stewardship and leadership under its umbrella. According to a market survey of Board of directors of various firms in 15 countries, the new hallmarks of vibrant corporate governance are, engaged leadership, organizational strategic alignment, openness to changing work dynamics and execution of strategic objectives (Heidrick \& Struggles International, Inc., 2014). In different academic and industry research the effectiveness of corporate governance has been questioned in various organizations such as entrepreneurs, private equity firms, big organizations, government owned firms, family controlled businesses and different stakeholders, varying from simple consumer up to the policy makers. The quest of these questions and issues like authority of executives, responsibilities of board of directors and their relationships within organization have developed a key insight on the subject and rational for managerial decisions in the context of risk and uncertainty.

Contrary to developed countries, the growth in corporate governance research in developing countries like Pakistan is still at its initial stage (Ameer, 2013). The reasons of ineffectiveness of corporate governance is the nature of ownership, irresponsible boards, lack of policies, partial implementation of governance codes and unwillingness of management to implement corporate governance norms (Dar, Naseem et al., 2011). Due to lack of corporate practices and its importance in business world resulted in corporate failure and scandals like PTCL, ENGRO group of companies, Mehran bank, Cresent bank fraud, and Taj Company are some of the examples in Pakistan (Gull et al., 2013). Over the years different authors have used various proxies to gauge the importance of corporate governance rules and practice and their impacts on business success and failure. This study will add into the existing literature on subject of corporate governance by defining different proxies such as board size, audit committee, Board independence, and CEO duality, and their impacts on firm value for KSE listed non-financial firms.

The remaining paper is organized as follow. In section 2 of this study we will cover the brief literature review and identify proxies for corporate governance. The research methodology is covered in section 3 and section 4 will cover the results and analysis. The conclusion of the study will be drawn in last section 5 of the study.

\section{Literature review and hypotheses development}

The Corporate governance is system of integrated and interdependent rules, regulations, processes and activities to manage and control the affairs of an organization. Starting from defining the responsibilities of Board of director to effectively govern organizations, explaining the shareholders' role to appoint directors and auditors to insure the smooth, efficient and accountable working environment, and structuring executives, managers and employees conduct of business affairs (Wahab $\&$ Holland, 2012). The jobs of Board of directors are to set the organizational philosophies, delineate an organizational strategic plane, insuring the availability of resources to mangers and inspiring them to materialize those goals, in an accountable way, and at the same time also to provide adequate and timely information for shareholders (Lopes \& Walker, 2012). Further, boards are accountable to shareholders and their actions are subject to strict laws and regulations (Cadbury, 1992). The topic of corporate governance is not new to academic research and it has always been under spot light by electronic press and media. Various studies have covered the area of owner's interest, corporate monopoly, board structure, management roles and authority, pay structure, bonuses and many more fine areas in various dynamics and different geographic boundaries (Dalton et al., 2007). But some new dynamics evolved in the field of corporate governance in past few decades are worth mentioning. Although, these developments are predominantly part of corporate world of advance economies, but sooner or latter its influence will felt in developing economies as well. 
First, the importance of agency problems has been highlighted by a series of events of corporate failure specifically in late 1990s and early 2000s, till recent times of subprime crisis (McDonnell \& King, 2013). The mega corporate scandals across the globe like BCCI, Enron, WorldCom, Northern Rock, Lehman Brothers, Freddy Mac, Fanny Mae and many more have motivated global corporate reforms and regulations in developed world, which was followed and adopted by developing world (Vintila \& Gherghina, 2013). The most prominent among these are Oxley Act in the United States, the Cadbury Code in the United Kingdom, Cromme Code in Germany, the Provisional Code of Corporate Governance for Securities Companies in China, and the Recomendações sobre Governança Corporativa in Brazil and Code of Corporate Governance in Pakistan (Kamran \& Shah, 2014). These corporate reforms have brought numerous managerial challenges and technicalities to managers and policy holders, which would have long lasting effects on organizational performance and conduct of daily affairs as highlighted in studies by Shipilov et al. (2010), Zhang and Wiersema (2009), and others.

The second important area in corporate governance is CEO's monitoring and compensation especially in big firms and financial conglomerates (Kacperczyk, 2009). This area has attracted massive media attention and criticism in the aftermath of corporate scandals in late 1990s and early 2000s, but after the global financial crisis in 2007, much more attention was given to address the dark area of corporate world and media investigation (Bednar, 2012; Pollock et al., 2008). Third and a very important dynamic in corporate governance was the response of politicians, regulators, and other authorities after the global melt down, which led direct and indirect interventions in many organization by governments (Cuomo et al., 2013). The capital induction by government specifically in financial sector and some other sectors give birth to a new way of organizing business. At the same time those sectors were brought under a very tight government defined rules of governance and goals under the "narrative of too big to fail". The government involvement in those sectors was mostly temporary, but in some instances governments maintained and even extended its stakes, resulting in state capitalism (Inoue et al., 2013).

Fourth, important development in the landscape of corporate governance is increased scrutiny of managers and executives by various stakeholders which were traditionally not responsible or bothered to take this sort of governance duties (Kacperczyk, 2009). These stakeholders are employees, unions and associations, social activists, and other groups which may not be directly responsible to run the affairs of corporations. For instance, increasing the number of managerial fraud and executives scams have been reported and shared by employees on various social media networks. Similarly, different social movement groups and organizations formed by employees, customers and other stakeholders are frequently putting pressure on managerial and executive decisions by organizing different seminars, public awareness campaigns and even calling for protests against the organization's polices (McDonnell \& King, 2013). This general public awareness and threat of boycotts have pushed the mangers to change their line of actions and forced them to alter organizational polices in line with the interest of all stakeholders, or broadly we can say that traditional profit oriented policies have been transformed into "triple bottom line, i.e. profit, people and planet (Jayachandran et al., 2013; King, 2008)

\subsection{Corporate Governance in Pakistan}

Historically in Pakistan the only available legal document to address the issues of corporate governance was Companies Ordinance, 1984. Latter on with changing global scenario and specifically after Asian financial crisis in 1990s, the OECD established the best practices for corporate governance which became a reference for most of developing countries (Javed \& Iqbal 2010). In year 2002, Securities Exchange Commission of Pakistan (SECP) issued Code of Corporate Governance (CCG) a comprehensive set of corporate governance rules, to establish the trust of various stakeholders on corporate management (Javed \& Iqbal 2007). The Code of Corporate Governance rules addressed different issues of corporate governance in its 47 sub clause, which was revised in 2012 again (Ameer, 2013). Subsequently, SECP also launched corporate governance rules for state-owned commercial entities in March 2013 which enhance corporate governance framework for public sector companies (Kamran \& Shah, 2014). In past one and half decade the area of corporate governance in Pakistan is under academic research and discussion and various aspects are investigated in local dynamics (Gull 
et al., 2013). Different authors have used various proxies to gauge the importance of corporate governance rules and practice and its impact on business success and failure. Some of those proxies of corporate governance such as board size, board independence, audit committee and CEO duality will be discussed in different dynamics and its association with firm value will identified.

\subsection{Board Size}

One of the main proxy to corporate governance is Board size, which means total number of directors on the board. Board of directors has a responsibility to ensure the implementation of corporate governance practices (Shleifer \& Vishn, 1997). According to Malik et al., (2014) the relationship between board size and firm value is still a fundamental issue for researcher. Some authors suggest that on average 5 to 16 members to be present at the board of an organization (Yasser et al., 2014). There are two schools of thoughts, large board and small size board, both have their own advantages and criticisms. But empirical research results are mixed across various countries and industry dynamics, and still it is a matter of research which school of thought to be followed in a particular situation (Yang et al., 2009). If the academic research is broadly analyzed, the imperial results in developing countries show a mix results on association of board size and firm (Nazir et al., 2009).

The advocate of small board size in organization (Lipton \& Lorsch, 1992; Jensen, 1993; Yermack, 1996; Mak \& Kusnadi, 2005) believe that, small board results in better for organizational performance, higher firm value and oversight. Smaller boards have the abilities to better communicate, coordinate and make decisions more, effectively. According to Yasser et al. (2011) the limited number of directors in the board has a positive impact on firm value. Similarly result were drawn in research conducted by Yermack (1996), Mak and Khusnadi (2001), Rouf (2011) and found in their studies a negative relationship between board size and firm value. They are of the view that, small boards results in efficient and smooth operations of organization.

But contrary to smaller board size in organization there is constant debate and support from empirical results to have large board in organization. Coleman and Biekpe (2006) argue that in developing countries like Ghana the board size and firm value have a positive relationship. Van den Berghe and Levrau (2004) argued that resource enrichment theory favors the large board size that increases the value of firm because members have managerial talent and they perform their duties effectively. There is also a view point that large board size has more control on top management and directors can prudently monitor the management performance and duties, which will eventually increase the value of the firm (Abdullah et al., 2012). The advocates of large board size suggested that firms that are large in size and complex require more expertise of their directors. So the presence of large board and more representation of directors are prerequisite for smooth operations and control. This variation in views on board size leads us to our first Hypothesis.

\section{$H_{1}$ : Board size has a significant impact on firm value.}

\subsection{Board Independence}

In pursuance of good governance and Code of Corporate Governance in Pakistan it is required for every listed company to have, at least, one third independent directors. At the same time the executive directors must not exceed $75 \%$ of board size (Yasser, et al., 2014). The simplest way to establish the independence of board in a firm is to find the presence of non-executive directors on a board (Gallo, 2005). There are some studies which hold the view that board independence and firm value have negative relationships. Similar results were found in the studies conducted by Bhagat and Bolton (2008), Dah et al. (2012) which show that the presence of independent directors would make things more completed and in most of the cases will result in delay of decisions making and thus will negatively affect the firm value.

The nonexecutive directors play a significant role in value creation for the firm. Various studies have been conducted in different sectors and geographic location across the globe such as Choi et al. (2006), Chan and li (2008), Nazir et al. (2009), Dunstan et al. (2011), Rouf (2011), Vintila and Gherghina 
(2013) found that there was a positive and significant relationships between board independent director and firm value. The presence of non-executive directors on board gives a positive signal to the investors and shareholders in particular and stakeholders in general that affairs of the firms are prudently monitored which also increase public confidence and subsequently add to firm value (Hassan \& Butt, 2009). According to agency theory the large proportion of independent directors affect positively the value of firm (Ramdani \& Van, 2009). The presence of independent directors on board will insure the effective timely monitoring and will also safeguard the interests of shareholders and in most of the times leads to on merit selection of CEO to run the organization (Khan \& Awan, 2012). The above discussion leads us to our second hypothesis of the study.

\section{$\mathrm{H}_{2}$ : Board Independence has significant impact on firm value.}

\subsection{Audit Committee}

The role of audit committee is no less important in pursuance of good governance. The role of audit committee is explained by Cadbury (1992) as "Audit committees provide a frame work within which the external auditor can assert his independence in the event of dispute with management and strengthen the position of internal audit function, by providing a greater degree of independence from management". In Pakistan according to Corporate Governance Code 2012, every listed company should has an audit committee. Audit committee consists of total three members all of which should be non-executive directors.

The role of audit committee is of great importance in good governance and protection of rights shareholders, which results in smooth operations and sense of responsibility across the firm (Aanu et al., 2014). Beside financial fairness of a corporation it also enhances the financial and managerial capabilities by insuring the implementation of good practices (Epps \& Cereola, 2008). Other studies like Anderson, Mansi and Reeb (2004), Matar et al. (2014) show the same positive association between firm value and audit committee. To reduce the agency problems it is very important to place a well functioning and an independent audit committee (Erickson et al., 2005). The size and the number of meeting of audit committee is of great interest in academic discussion, and have been frequently associated with firm value (Abdelsalam \& Street, 2007). Various studies conducted such as Dar et al. (2011), Rouf (2011), Chughtai and Tahir (2015) came up with results that audit committee and firm value have negative relation. At same time, there is also a risk of financial misreporting if the size of audit committee is increased too much (Chaganti et al., 1985).

\section{$H_{3}$ : The Size of audit committee has a significant impact on firm value.}

\subsection{CEO Duality}

The CEO duality means that the CEO is also holding a position as a Chairman of the board of directors. According to Yang and Zhao (2014) the separation of post of CEO and the Chairman of the Board is one of the most debatable corporate governance issues in recent years. The Board of directors will define duties to Chairman and CEO, whether these are the same or separate. The relationship between CEO duality and firm value, have been examined in numerous occasions and circumstances, but there results are always mixed and inconclusive (Wellalage \& Locke, 2011). Some of the researchers are in the favor of CEO duality and came up with positive association between CEO duality and firm value. With fast evolving work dynamics it is important to have a clear chain of authority and control, and it would not be possible without CEO duality (Gillan, 2006). The same results are confirmed by Rouf (2011) which found in his study that there was a positive relationships between CEO duality and firm value. On other hand authors like Fosberg (2004), Sanda et al. (2005) confirmed that when CEO and chairman of the board positions are separate then there would be more valuable prepositions for the firms. The integration of power in one hand is not the norm of today's work environment and it will bring negative effects on a firm performance especially in long run (Combs et al., 2007). Almost similar result was drawn by Agrawal and Chadha (2005) that CEO and chairman of the board positions should not be held by the same person. This led us to our fourth hypothesis.

H4: CEO duality has significant negative impact on firm value. 


\subsection{Firm Value}

Good corporate governance is believed to be one of the important factors in improving the value of the firm. There is a growing body of literature in finance which provides evidence on the linkage between corporate governance practices, corruption, legal infrastructure and firm performance and value (Ficici \& Aybar, 2012). According to Black et al. (2003) the corporate governance is an important factor of explaining the market value of companies. They found in their study that there was a positive and significant relationships between corporate governance index and firm value. There is a constant support to confirm the notion that good corporate governance would increase the value of the firm (Bauer et al., 2004 )

The value of firm is the amount of benefits by shareholder from the share of the firm. In empirical studies Tobin's Q has been widely used as a proxy to measure the value of firm (Lindenberg \& Ross, 1981; Amit \& Wernerfelt, 1990; Palia, 2001; and Bhagat \& Jefferis, 2002). Tobin's Q is defined as the ratio of the Market Value of Assets (equity and debt) to the Replacement Value of Assets. According to Lang and Litzenberger (1989), Tobin's q is a growth measure and a high Tobin's q value shows that growth increase.

Tobin's Q was calculated by a following formula in previous studies.

$$
\text { Tobin's } Q=\frac{(T A-B E)+M V E}{T A}
$$

Independent variables

Corporate governance

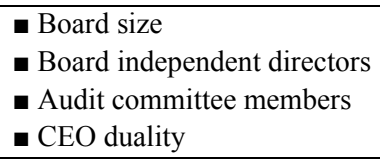

Control variable
Dependent variable

$\underline{\text { Firm value }}$

- Tobin's Q

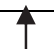

Firm size

Fig. 1. The proposed study

\section{Research methodology}

In this study we used 5 years panel data from time period 2010-2014, using stratified random sample by dividing different firms (nonfinancial firms) in to different sectors on Karachi Stock Exchange. From different sector 91 non-financial firms were selected using simple random sampling. For data analysis we used E-Views software and applied different test such as Panel data regression, Hausman test, Random Effect Regression. In this study following dependent, independent and control variable are used.

\section{Table 1}

Variable Definition

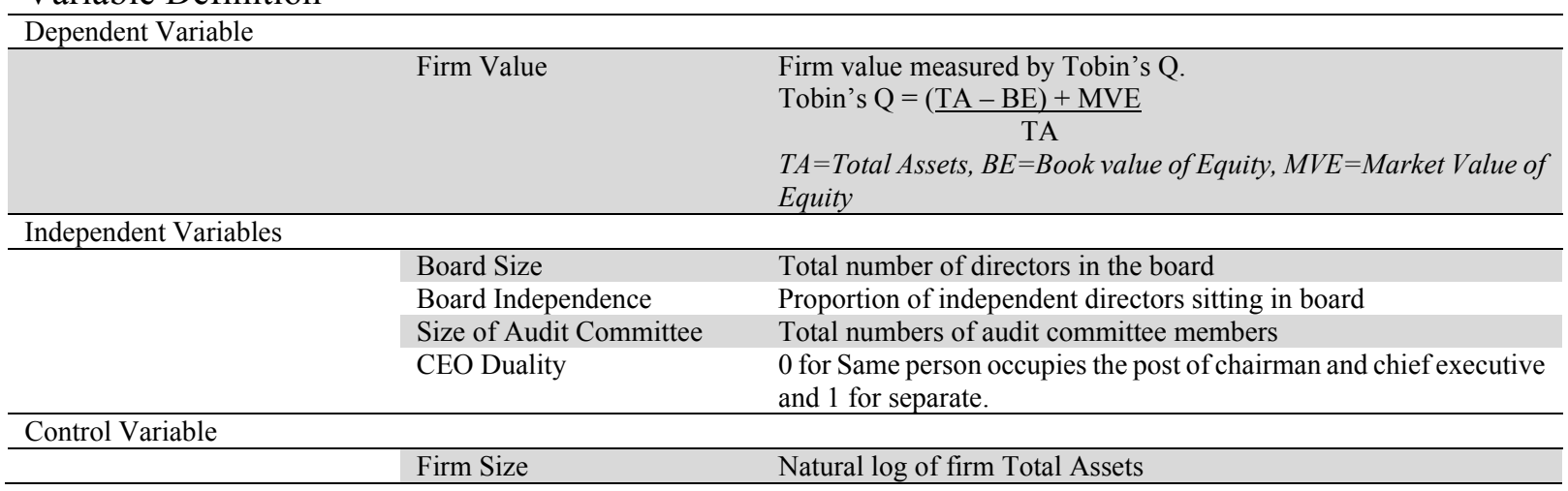

To analyze the data following model is used. 
$Q=\alpha+\beta_{1}(B S)_{i t}+\beta_{2}(B I D)_{i t}+\beta_{3}(A C)_{i t}+\beta_{4}(C D)_{i t}+\beta_{5}(F S)_{i t}+\mu_{i}$

In this model Tobin's $\mathrm{Q}$ is used for firm value as a dependent variable and board size (BS), board independent directors (BID), audit committee (AC), CEO Duality (CD), as independent variables, and firm size (FS) used as a control variable. $\alpha$ is the intercept and $\beta$ shows slope $\mathrm{t}=$ time.

\section{Results and Analysis}

In this section, we discuss about the data and its results. The collected data are analyzed by using Eviews software and descriptive statistics and random effect techniques are applied on the data.

\subsection{Descriptive Statistics}

The descriptive statistics explain the features of the data quantitatively. Following descriptive statistics in Table 2 shows the mean, median, standard deviation of each variable. The mean value of Tobin's Q is 1.49 of sampled of 91 firms listed on Karachi stock exchange. The average board size (BSIZE) of the sampled firms is 8 with standard deviation of 1.46. The minimum members are 6 and maximum members are 14 and average proportion of independent directors in the board is 5.27 with a standard deviation of 2.11. The minimum proportion of independent directors in the board 0 and the maximum limit is 13. This indicates that on average the independent nonexecutive director is approximately $5.27 \%$ of the board. The average size of audit committee in the firms is 3 with standard deviation of 0.68 . The results show that audit committee consists of minimum 2 and maximum 6 members. The results indicate that $74 \%$ person holding the position of holding the position of CEO and chairman separately. Only $26 \%$ of them holds CEO and chairman position at the same time.

Table 2

Descriptive Statistics

\begin{tabular}{lllllll}
\hline & TOBIN_Q & FIRM_SIZE & B_SIZE & BIND & BACOM & CEOD \\
\hline Mean & 1.498833 & 22.63969 & 8.070330 & 5.270330 & 3.340659 & 0.742857 \\
Median & 1.004000 & 22.49500 & 8.000000 & 5.000000 & 3.000000 & 1.000000 \\
Maximum & 12.69000 & 27.66500 & 14.00000 & 13.00000 & 6.000000 & 1.000000 \\
Minimum & 0.014000 & 16.90300 & 6.000000 & 0.000000 & 2.000000 & 0.000000 \\
Std. Dev. & 1.480268 & 1.722027 & 1.456982 & 2.108170 & 0.686878 & 0.437540 \\
Skewness & 3.824173 & -0.084648 & 1.691476 & 0.730426 & 2.014800 & -1.111325 \\
Kurtosis & 22.36419 & 4.009390 & 6.034230 & 5.295054 & 6.507963 & 2.235043 \\
\hline Jarque-Bera & 8217.849 & 19.85939 & 391.5070 & 140.3174 & 541.1367 & 104.7511 \\
Probability & 0.000000 & 0.000049 & 0.000000 & 0.000000 & 0.000000 & 0.000000 \\
\hline Sum & 681.9690 & 10301.06 & 3672.000 & 2398.000 & 1520.000 & 338.0000 \\
Sum Sq. Dev. & 994.8023 & 1346.281 & 963.7495 & 2017.749 & 214.1978 & 86.91429 \\
\hline Observations & 455 & 455 & 455 & 455 & 455 & 455 \\
\hline
\end{tabular}

\subsection{Hausman test for random effect regression or fixed effect regression}

For analysis of data first we have used Hausman test to choose between Random Effect and Fixed Effect. We got insignificant result from Hausman test i.e. p-value of 0.3179, which leads us to use random effect model to analyze data.

\section{Table 3}

\section{Hausman Test}

Correlated Random Effects - Hausman Test

Equation: Untitled

Test cross-section random effects

\begin{tabular}{cccc}
\hline Test Summary & $\begin{array}{c}\text { Chi-Sq. } \\
\text { Statistic }\end{array}$ & $\begin{array}{c}\text { Chi-Sq. } \\
\text { d.f. }\end{array}$ & Prob. \\
\hline Cross-section random & 5.882146 & 5 & 0.3179 \\
\hline
\end{tabular}

\subsection{Results and Discussion}

The result of Table 4 shows that board size p-value is 0.048 which is significantly associated with firm value, and thus we accept our first hypothesis, i.e. $H_{1}$ : Board size has a significant impact on firm value. 
But the coefficient of board size is negative i.e. -0.166 ; which means that board size is negatively but significantly correlated with firm value (Tobin's Q). This shows that small board size will lead to a better firm performance, earlier studies (Goodstein et al., 1994; Judge \& Zeithaml,1992; Ran et al., 2014)) confirmed this notion and identified multiple issue like slow decision making, low R\&D spending, higher fixed asset investments and free rider problem with increasing the size of board in organizations. The Board independent directors p-value is 0.002 which shows that null hypothesis will be rejected and our second hypothesis will be accepted, i.e. $\mathrm{H}_{2}$ : Board Independence has significant impact on firm value. The coefficient of Board Independent director's is positive i.e. 0.157. So the results show that Board independent directors have a significant and positive relationship with firm value. It means more nonexecutive directors in the board will increase the value of firm. It will also give a positive signal to the investors and shareholders that firm are being effectively monitored which will add to public confidence and ultimately results in value of firm (Hassan \& Butt, 2009). According to agency theory the adequate control of management authority is not possible without the existence of independence of board and to insure the avoidance of possible opportunism and nepotism of management in greater interest of shareholders (Fama \& Jensen, 1983; Jensen, 1993; Jensen \& Meckling, 1976). The presence of independent directors will also reduce information asymmetries and agency costs between shareholders and management (Chang, 2009; Daily, 1995; Fich \& Slezak, 2008).

Board audit committee p-value is 0.013 which means null hypothesis will be rejected and accepts our third hypothesis i.e. $H_{3}$ : The Size of audit committee has a significant impact on firm value. The coefficient value is 0.301 which means board audit committee is positively and significantly related with Tobin's Q. The result shows that an increase in the size of audit committee will increase the value of the firm. According to DeAngelo (1981) the independence of audit committee is a key to detect financial manipulation and errors. At the same time the presence of auditor from large and reputable auditing firms will insure financial and operational stability as compared to auditors from smaller auditing firms (Palmrose, 1988). Yasser et al. (2011) also found in their study that audit committee had a positive and significant impact on firm value. The CEO duality variable's p-value is 0.696 ; which is greater than significance level of 5\%, so the null hypothesis is accepted and thus we reject our fourth hypothesis i.e. H4: CEO duality has significant impact on firm value. So, the CEO duality has insignificant and negative impact on firm value. Some authors argue that separation of a role of CEO and chairman is a key to effectiveness of board and monitoring controls (Baysinger \& Hoskisson, 1990; Jensen, 1993). The research conducted by Amba (2013) also confirm the same results and further suggested that CEO duality create agency cost and decrease the value of firm. Chughtai and Tahir (2015) found in their study CEO duality has insignificant impact on firm value.

\section{Table 4}

Results of Panel Regression

Dependent Variable: TOBIN Q

Method: Panel EGLS (Cross-section random effects)

Sample: 20102014

Periods included: 5

Cross-sections included: 91

Total panel (balanced) observations: 455

\begin{tabular}{lllll}
\hline Variable & Coefficient & Std. Error & t-Statistic & Prob. \\
\hline C & 1.076660 & 1.471453 & 0.731698 & 0.4647 \\
FIRM_SIZE & -0.000772 & 0.062046 & -0.012443 & 0.9901 \\
B_SIZE & -0.166636 & 0.082801 & -2.012493 & 0.0448 \\
BIND & 0.157560 & 0.051203 & 3.077146 & 0.0022 \\
BACOM & 0.301183 & 0.121833 & 2.472093 & 0.0138 \\
CEOD & -0.070110 & 0.179806 & -0.389921 & 0.6968 \\
\hline Weighted Statistics & & & & \\
\hline R-squared & 0.037693 & & & 0.983023 \\
Adjusted R-squared & 0.026976 & S.D. dependent var & & 422.1798 \\
S.E. of regression & 0.969674 & Sum squared resid & & \\
F-statistic & 3.517367 & & & \\
Prob(F-statistic) & 0.003950 & & & \\
\hline
\end{tabular}




\section{Conclusion}

The relationship between corporate governance and firms' value has been enormously documented in various countries especially in developed world. But there is a clear gap in academic research in Pakistan on this issue. This study aimed to address that gap in current academic research. Different proxies of corporate governance such as board size, board independence, audit committee and CEO duality were identified with the help of existing literature and their impacts on firm value were identified. The results have shown that board size had a negative but significant impact on value of the firm. The average board size of the sampled firms was 8 , with the minimum members of 6 and the maximum members of 14 . The other variable of corporate governance used in the study was existence of non-executive directors in the board, which was brought under discussion to gauge the independence of a board in their decisions. The results have shown that non-executive directors had significant and positive impacts on firm value. On average there were 5-6 independent directors in firms, which is on higher side especially by considering the average board size of 8 members. Audit committee plays an important role to implement corporate governance practices and to increase the value of the firm. The results of the study have shown that audit committee had a positive and significant relationship with firm value. The average size of audit committee in KSE listed firms was 3 with the minimum of 2 and the maximum of 6 members. The CEO duality had insignificant and negative impact on firm value. In $74 \%$ firms, the CEO and chairmen positions were held by different people and only in $26 \%$ of the firms the position of CEO and Chairman was held by the same person. The position of CEO and Chairman should be separated as it would result in conflicts of interest and also may increase in agency cost.

This study is just a beginning of a long journey. For future research on subject area more corporate governance variables like family ownership structure, board size characteristics, women role in the board and impact of firm value can be taken in to consideration

\section{References}

Aanu, O. S., Odianonsen, I. F., \& Foyeke, O. I. (2014). Effectiveness of audit committee and firm financial performance in Nigeria: an empirical analysis. Journal of Accounting and Auditing, 1-11. Article ID 301176.

Abdelsalam, O. H., \& Street, D. L. (2007). Corporate governance and the timeliness of corporate internet reporting by UK listed companies. Journal of International Accounting, Auditing and Taxation, 16(2), 111-130.

Abdullah, F., Shah, A., \& Khan, S. U. (2012). Firm performance and the nature of agency problems in insiders-controlled firms: Evidence from Pakistan. The Pakistan Development Review, 51(4), 161 182.

Agrawal, A., \& Chadha, S. (2005). Corporate governance and accounting scandals. Journal of law and economics, 48(2), 371-406.

Al-Matar, E. M., Al-Swidi, A. K., \& Fadzil, F. H. B. (2014). The Effect of Board of Directors Characteristics, Audit Committee Characteristics and Executive Committee Characteristics on Firm Performance in Oman: An Empirical Study. Asian Social Science, 10(11), 149.

Amba, S. M. (2013). Does CEO duality enhance firms business performance? Empirical evidence from Bahrain. International Journal of Business and Social Science, 4(6), 88-91.

Ameer, B. (2013). Corporate governance-issues and challenges in Pakistan. International Journal of Academic Research in Business and Social Sciences, 3(4), 79.

Amit, R., \& Wernerfelt, B. (1990). Why do firms reduce business risk? Academy of Management Journal, 33(3), 520-533.

Anderson, R. C., Mansi, S. A., \& Reeb, D. M. (2004). Board characteristics, accounting report integrity, and the cost of debt. Journal of accounting and economics, 37(3), 315-342.

Bauer, R., Guenster, N., \& Otten, R. (2004). Empirical evidence on corporate governance in Europe: The effect on stock returns, firm value and performance. Journal of Asset Management, 5(2), 91104.

Baysinger, B., \& Hoskisson, R. E. (1990). The composition of boards of directors and strategic control: Effects on corporate strategy. Academy of Management review, 15(1), 72-87. 
Bednar, M. K. (2012). Watchdog or lapdog? A behavioral view of the media as a corporate governance mechanism. Academy of Management Journal, 55(1), 131-150.

Bhagat, S., \& Bolton, B. (2008). Corporate governance and firm performance. Journal of corporate finance, 14(3), 257-273.

Bhagat, S., \& JEFFERIS, R. (2002). The Econometrics of Corporate Governance Studies. Cambgidge: MIT Press.

Black, B. S., Hideaki, M., Jang, J.-s., Johnson, S., \& Kim, E. H. (2003). Does corporate governance affect firm value? Evidence from Korea.

Butt, S. A., \& Hasan, A. (2009). Impact of ownership structure and corporate governance on capital structure of Pakistani listed companies. International Journal of Business \& Management, 4(2).

Cadbury, A. (1992). Report of the committee on the financial aspects of corporate governance (Vol. 1): Gee.

Chaganti, R. S., Mahajan, V., \& Sharma, S. (1985). Corporate board size, composition and corporate failures in retailing industry. Journal of Management Studies, 22(4), 400-417.

Chan, K. C., \& Li, J. (2008). Audit committee and firm value: evidence on outside top executives as expert-independent directors. Corporate Governance: An International Review, 16(1), 16-31.

Chang, C. (2009). The corporate governance characteristics of financially distressed firms: Evidence from Taiwan. Journal of American Academy of Business, 15(1), 125-132.

Choi, J. J., Park, S. W., \& Yoo, S. S. (2007). The value of outside directors: Evidence from corporate governance reform in Korea. Journal of Financial and Quantitative Analysis, 42(04), 941-962.

Chughtai, M. W., \& Tahir, W. A. (2015). Effects of Corporate Governance on Organization Performance: Evidence from Banking Sector of Pakistan. IOSR Journal of Business and Management, 17(3), 75-82.

Combs, J. G., Ketchen, D. J., Perryman, A. A., \& Donahue, M. S. (2007). The moderating effect of CEO power on the board composition-firm performance relationship. Journal of Management Studies, 44(8), 1299-1323.

Cuomo, F., Zattoni, A., \& Valentini, G. (2012). The effects of legal reforms on the ownership structure of listed companies. Industrial and Corporate Change, dts015.

Dalton, D. R., Hitt, M. A., Certo, S. T., \& Dalton, C. M. (2007). 1 The Fundamental Agency Problem and Its Mitigation: Independence, Equity, and the Market for Corporate Control. The academy of management annals, 1(1), 1-64.

Dar, L., Naseem, M. A., Niazi, G., \& Rehman, R. U. (2011). Corporate governance and firm performance: A case study of Pakistan oil and gas companies listed in Karachi stock exchange. Global Journal of Management and Business Research, 11(8), 1-11.

DeAngelo, L. E. (1981). Auditor size and audit quality. Journal of Accounting and Economics, 3(3), 183-199.

Dunstan, K. L., Keeper, T., Truong, T. P., \& Van Zijl, T. (2011). The Influence of Board Structure on the Value of NZX Listed Firms and its Association with Growth Options. Available at SSRN 2028629.

Epps, R. W., \& Cereola, S. J. (2008). Do institutional shareholder services (ISS) corporate governance ratings reflect a company's operating performance? Critical Perspectives on Accounting, 19(8), $1135-1148$.

Erickson, J., Park, Y. W., Reising, J., \& Shin, H.-H. (2005). Board composition and firm value under concentrated ownership: the Canadian evidence. Pacific-Basin Finance Journal, 13(4), 387-410.

Fama, E. F., \& Jensen, M. C. (1983). Separation of ownership and control. The Journal of Law \& Economics, 26(2), 301-325.

Fich, E. M., \& Slezak, S. L. (2008). Can corporate governance save distressed firms from bankruptcy? An empirical analysis. Review of Quantitative Finance and Accounting, 30(2), 225-251.

Ficici, A., \& Aybar, C. B. (2012). Corporate Governance and Firm Value in Emerging Markets an Empirical Analysis of ADR Issuing Emerging Market Firms. EMAJ: Emerging Markets Journal, 2(1), 38-51. 
Fosberg, R. H. (2004). Agency problems and debt financing: leadership structure effects. Corporate Governance: The international Journal of Business in Society, 4(1), 31-38.

Gallo, M. Á. (2005). Independent board directors: How to improve their contribution to the family business. IESE Business School Discussion Paper(589).

Gillan, S. L. (2006). Recent developments in corporate governance: An overview. Journal of Corporate Finance, 12(3), 381-402.

Gull, A. A., Saeed, A., \& Abid, A. (2013). Corporate governance and performance: An empirical evidence from textile sector of Pakistan. African Journal of Business Management, 7(22), 2112.

Hewa Wellalage, N., \& Locke, S. (2011). Does CEO duality is really matter? Evidence from an emerging market. Evidence from an Emerging Market (May 29, 2011). Corporate Ownership \& Control, 8(4).

Huyghebaert, N., \& Wang, L. (2012). Expropriation of minority investors in Chinese listed firms: The role of internal and external corporate governance mechanisms. Corporate Governance: An International Review, 20(3), 308-332.

Inoue, C. F., Lazzarini, S. G., \& Musacchio, A. (2013). Leviathan as a minority shareholder: Firm-level implications of state equity purchases.Academy of Management Journal, 56(6), 1775-1801.

Javed, A. Y., \& Iqbal, R. (2007). Relationship between corporate governance indicators and firm value: A case study of Karachi stock exchange. PIDE Working Papers.

Javid, A. Y., \& Iqbal, R. (2010). Corporate governance in Pakistan: Corporate valuation, ownership and financing. Working Papers \& Research Reports, 2010.

Jayachandran, S., Kalaignanam, K., \& Eilert, M. (2013). Product and environmental social performance: Varying effect on firm performance. Strategic Management Journal, 34(10), 1255 1264.

Jensen, M. C. (1993). The modern industrial revolution, exit, and the failure of internal control systems. The Journal of Finance, 48(3), 831-880.

Jensen, M. C., \& Meckling, W. H. (1976). Theory of the firm: Managerial behavior, agency costs and ownership structure. Journal of financial economics, 3(4), 305-360.

Kacperczyk, A. (2009). With greater power comes greater responsibility? Takeover protection and corporate attention to stakeholders. Strategic Management Journal, 30(3), 261-285.

Kamran, K., \& Shah, A. (2014). The impact of corporate governance and ownership structure on earnings management practices: Evidence from Listed Companies in Pakistan. The Lahore Journal of Economics, 19(2), 27-70.

Khan, A., \& Awan, S. H. (2012). Effect of board composition on firm's performance: A case of Pakistani listed companies. Interdisciplinary Journal of Contemporary Research in Business, 3(10), 853.

King, B. G. (2008). A political mediation model of corporate response to social movement activism. Administrative Science Quarterly, 53(3), 395-421.

King, T.-H. D., \& Wen, M.-M. (2011). Shareholder governance, bondholder governance, and managerial risk-taking. Journal of Banking \& Finance, 35(3), 512-531.

Kyereboah-Coleman, A., \& Biekpe, N. (2006). The relationship between board size, board composition, CEO duality and firm performance: Experience from Ghana. Corporate Ownership and Control, 4(2), 114-122.

Lang, L. H., \& Litzenberger, R. H. (1989). Dividend announcements: Cash flow signalling vs. free cash flow hypothesis? Journal of Financial Economics, 24(1), 181-191.

Lindenberg, E. B., \& Ross, S. A. (1981). Tobin's q ratio and industrial organization. Journal of Business, 1-32.

Lipton, M., \& Lorsch, J. W. (1992). A modest proposal for improved corporate governance. The Business Lawyer, 59-77.

Mak, Y. T., \& Kusnadi, Y. (2005). Size really matters: Further evidence on the negative relationship between board size and firm value. Pacific-Basin Finance Journal, 13(3), 301-318.

McDonnell, M.-H., \& King, B. (2013). Keeping up appearances reputational threat and impression management after social movement boycotts. Administrative Science Quarterly, 58(3), 387-419. 
Nazir, M., Haque, A., \& Ali, S. (2009). Can board mechanism affect the firm value in Pakistan. Corporate Ownership and Control, 6(3), 308-317.

Palia, D. (2001). The endogeneity of managerial compensation in firm valuation: A solution. Review of Financial Studies, 14(3), 735-764.

Palmrose, Z.-V. (1988). 1987 Competitive manuscript co-wWinner: An analysis of auditor litigation and audit service quality. Accounting Review, 55-73.

Pindado, J., Requejo, I., \& Torre, C. (2012). Do family firms use dividend policy as a governance mechanism? Evidence from the Euro zone. Corporate Governance: An International Review, 20(5), 413-431.

Pollock, T. G., Rindova, V. P., \& Maggitti, P. G. (2008). Market watch: Information and availability cascades among the media and investors in the US IPO market. Academy of Management Journal, 51(2), 335-358.

Ramdani, D., \& van Witteloostuijn, A. (2009). Board independence, CEO duality and firm performance: A quantile regression analysis for Indonesia, Malaysia, South Korea and Thailand.

Renders, A., \& Gaeremynck, A. (2012). Corporate governance, principal-principal agency conflicts, and firm value in European listed companies. Corporate Governance: an international review, 20(2), 125-143.

Rouf, M. (2011). The relationship between corporate governance and value of the firm in developing countries: Evidence from Bangladesh. The International Journal of Applied Economics and Finance, 5, 237-244.

Sanda, A. U., Mikailu, A. S., \& Garba, T. (2010). Corporate governance mechanisms and firms' financial performance in Nigeria. Afro-Asian Journal of Finance and Accounting, 2(1), 22-39.

Shipilov, A. V., Greve, H. R., \& Rowley, T. J. (2010). When do interlocks matter? Institutional logics and the diffusion of multiple corporate governance practices. Academy of Management Journal, 53(4), 846-864.

Shleifer, A., \& Vishny, R. (1999). A survey of corporate governance. Journal of Finance, LII (2), June, 737-83. International Library of Critial Writing in Economics, 106, 20-66.

Smith, W. K. (2014). Dynamic decision making: A model of senior leaders managing strategic paradoxes. Academy of Management Journal, 57(6), 1592-1623.

Van den Berghe, L. A., \& Levrau, A. (2004). Evaluating Boards of Directors: what constitutes a good corporate board? Corporate Governance: An International Review, 12(4), 461-478.

Vintila, G., \& Gherghina, S. C. (2013). Board of directors independence and firm value: empirical evidence based on the bucharest stock exchange listed companies. International Journal of Economics and Financial Issues, 3(4), 885.

Wahab, N. S. A., \& Holland, K. (2012). Tax planning, corporate governance and equity value. The British Accounting Review, 44(2), 111-124.

Wong, S. Y., Loo, S. C., Mohd, R., \& Mohamad, S. (2009). The effect of board structure and institutional ownership structure on earnings management. International Journal of Economics and Management, 3(2), 332-353.

Yang, T., \& Zhao, S. (2014). CEO duality and firm performance: Evidence from an exogenous shock to the competitive environment. Journal of Banking \& Finance, 49, 534-552.

Yaseer, Q., Abdullah, A. M., \& Suriya, A. R. (2014). CEO duality structure and firm performance in Pakistan. Asian Journal of Accounting and Governance, 5, 57-69.

Yasser, Q. R., Entebang, H. A., \& Mansor, S. A. (2011). Corporate governance and firm performance in Pakistan: The case of Karachi Stock Exchange (KSE)-30. Journal of economics and international finance, 3(8), 482-491.

Yermack, D. (1996). Higher market valuation of companies with a small board of directors. Journal of financial economics, 40(2), 185-211.

Zhang, Y., \& Wiersema, M. F. (2009). Stock market reaction to CEO certification: The signaling role of CEO background. Strategic Management Journal, 30(7), 693-710. 